\title{
Necessity of performing routine tests in trauma patients referring to emergency departments
}

\author{
Konieczność wykonywania rutynowych badań u pacjentów z urazami \\ zgłaszających się na szpitalne oddziały ratunkowe
} \author{
Seyed Hossain Montazer ${ }^{5}$, Seyyedeh Masoume Pashaei ${ }^{6}$ \\ ${ }^{1}$ Gut and Liver Research Centre, Faculty of Medicine, Mazandaran University of Medical Sciences, Sari, Iran \\ 2Diabetes Research Centre, Faculty of Medicine, Mazandaran University of Medical Sciences, Sari, Iran \\ ${ }^{3}$ Mazandaran University of Medical Sciences, Sari, Iran \\ ${ }^{4}$ Education Development Centre, Mazandaran University of Medical Sciences, Sari, Iran \\ ${ }^{5}$ Orthopaedic Research Centre, Faculty of Medicine, Mazandaran University of Medical Sciences, Sari, Iran \\ ${ }^{6}$ Faculty of Medicine, Mazandaran University of Medical Sciences, Sari, Iran
}

Fatemeh Jahanian ${ }^{1}$, Seyed Mohammad Hosseininejad², Nadia Rostamian³ ${ }^{3}$ Siavash Moradi ${ }^{4}$, Farzad Bozorgi ${ }^{5}$,

Medical Studies/Studia Medyczne 2019; 35 (4): 271-276

DOI: https://doi.org/10.5114/ms.2019.91243

Key words: routine tests, trauma, emergency, diagnostic value, lab tests.

Słowa kluczowe: rutynowe badania, uraz, nagły wypadek, wartość diagnostyczna, badania laboratoryjne.

\begin{abstract}
Introduction: Congestion and unnecessary tests in Emergency Departments are a serious problem, leading to long waiting times and delays in providing care.

Aim of the research: In the present study, the necessity of routine laboratory tests that were ordered for trauma patients in an Emergency Department are evaluated.

Material and methods: Patients' physical and clinical condition along with frequency and results of the routine tests requested were recorded. All patients were followed up to the final diagnosis. All tests were analysed in the central and emergency laboratory of the hospital.

Results: A total of 340 cases completed this descriptive-cross sectional study, with a mean age of $32.77 \pm 12.47$ years, and $71.8 \%$ were male. The most common type of trauma was car occupant (41.8\%), the most common injured body region was lower extremity (36.88\%), the most common clinical finding was pain $(92.4 \%)$, and the most common ordered routine test was CBC; the only statistically significant relationship was between swelling (clinical finding) and biochemistry results $(p=0.034)$. The final diagnosis in $150(44.1 \%)$ cases was fracture. The mean admission time was $25.09 \pm 8.79 \mathrm{~h}$, mean hospitalisation time was $3.00 \pm 2.05$ days, and the relationship between final diagnosis and lab results was not statistically significant. Conclusions: The findings revealed that the most frequently ordered lab tests in patients presented to our Emergency Department with major trauma is CBC, followed by PT and PTT. In addition, routine laboratory tests are not targeted; therefore, reducing unnecessary ordered lab tests may reduce health costs.
\end{abstract}

\section{Streszczenie}

Wprowadzenie: Przepełnienie szpitalnych oddziałów ratunkowych oraz wykonywanie niepotrzebnych badań stanowią poważny problem, co skutkuje długim czasem oczekiwania pacjentów i opóźnieniami w dostarczaniu im odpowiedniej opieki.

Cel pracy: W pracy przeanalizowano zasadność wykonywania rutynowych badań laboratoryjnych zlecanych u chorych przebywających na szpitalnych oddziałach ratunkowych.

Materiał i metody: Zebrano dane dotyczące stanu fizycznego i klinicznego pacjentów, częstości rutynowo zlecanych u nich badań oraz ich wyników. Wszystkich pacjentów kontrolowano do czasu ustalenia ostatecznego rozpoznania. Wszystkie badania analizowano w szpitalnym laboratorium centralnym i laboratorium SOR-u.

Wyniki: W ramach badania przekrojowego pełną analizą objęto łącznie 340 przypadków. Średnia wieku pacjentów wynosiła 32,77 $\pm 12,47$ roku, a 71,8\% grupy stanowili mężczyźni. Urazy występowały najczęściej u użytkowników samochodów (41,8\%), a najczęstszą lokalizacją urazu była kończyna dolna (36,88\%). Najczęstszym objawem klinicznym był ból $(92,4 \%)$, a najczęściej zlecanym rutynowym badaniem była morfologia krwi obwodowej. Jedyną statystycznie istotną zależność stwierdzono między obrzękiem (objaw kliniczny) a badaniem biochemicznym $(p=0,034)$. W $150(44,1 \%)$ przypadkach ostatecznym rozpoznaniem było złamanie. Średni czas przyęcia wynosił 25,09 $\pm 8,79$ godziny, średni czas hospitalizacji 
3,00 $\pm 2,05$ dnia, a zależność pomiędzy ostatecznym rozpoznaniem a uzyskanymi wynikami badań nie była istotna statystycznie.

Wnioski: W badaniu stwierdzono, że wśród pacjentów z poważnym urazem zgłaszających się na nasz SOR najczęściej zlecanymi badaniami laboratoryjnymi są morfologia krwi obwodowej, a następnie PT i PTT. Rutynowe badania laboratoryjne nie są ukierunkowane, dlatego ograniczenie niepotrzebnie zlecanych badań może obniżyć koszty opieki medycznej.

\section{Introduction}

Hospital Emergency Departments impose an excessive workload on nurses working in them, mainly due to their critical role and unpredictable nature. Congestion in Emergency Departments and unnecessary tests are a serious problem around the country, leading to long waiting times for patients and delays in providing them with care. This is an important point regarding patient satisfaction in terms of time and cost. Therefore, initial examination and prioritisation of patients referring to emergency departments are necessary. Hospitals consist of different departments in order to deliver different health services to the patients, and the relationships between these departments should be coherent so that the organisation can effectively perform its tasks, because any defect in any of the departments can lead to a problem in the patients' health service delivery [1].

Emergency Departments are responsible for prompt and comprehensive handling of all emergency and trauma patients, and they serve as one of the essential wards in General Hospitals [2].

Playing a vital role, Emergency Department serve as the core of the hospital, and regular conduct of activities in this unit can save many lives. No hospital can be considered as an ideal medical centre without an active Emergency Ward and its appropriate functioning: in the case of such a deficiency, other hospital services will be affected by this major incapacity [3].

Most often, the patients' first experience is linked to an Emergency Unit, and due to the necessity of urgent care and special treatments, understanding the patient's most critical needs is essential in the Emergency Rooms [4]. Nearly $28 \%$ of patients referred to the Emergency Departments are admitted to different wards of the hospital; therefore, health budgets must be optimised in order to maximise health care services [5].

According to the patients' main problems, the most appropriate laboratory and screening tests should be performed in Emergency Departments. Medical knowledge, traditions, customs, institutional policies, and legal concerns may affect a doctor's decisions on diagnostic tests. Tests are carried out for many different reasons, but the most important one is to facilitate the patients' diagnosis and therapy [6]. However, the diagnostic accuracy and the necessity of some tests may not be specified when ordered by the physician. Another issue is the time spent on each test. The time used up on unnecessary tests in the Emergency Department is highly significant. Finally, it should be noted that each test has its own cost [6]. Increased costs and demands in the limited time of emergency care threatens the chances of success in emergency rooms and care facilities [7]. In critical conditions, the situation is even worse due to time-consuming management, high cost, and the time taken for unnecessary X-ray imaging and laboratory tests. Today, there is a growing trend in all departments to speed up actions, reducing costs, and preventing unnecessary tests in the Emergency Department [8].

For example, in the Advanced Truama Life Support (ATLS) protocol, which was defined by the American College of Surgeons (ACS) for emergency trauma patients, some of the most commonly used tests include haemoglobin (HB) or haematocrit (HCT) evaluations, biochemical analysis including liver and renal function tests, urine, PA chest X-ray, PA pelvic X-ray, lateral cervical X-ray, and Focused Assessment with Sonography for Trauma (FAST) [9].

Nowadays, for all major trauma patients and those with multiple trauma, who are asymptomatic in clinical examination, the diagnostic and economic value of imaging and the necessity of routine tests that are mentioned in the ATLS protocol are under question with ongoing studies, because every unnecessary test imposes an extra burden in the form of economic and medical costs, both for patients and the health systems [10].

\section{Aim of the research}

In the present study, the necessity of routine laboratory tests that were ordered for trauma patients in an Emergency Department are evaluated in order to determine the extent of normal and abnormal test results, along with analysis to see if the tests were ordered correctly and were correlated with patients' clinical findings and their final diagnosis.

\section{Material and methods}

The present study is an observational-cross-sectional research, which was conducted in the Emergency Department of Imam-khomein Hospital in 2017.

The study population consisted of all major or multiple trauma patients referred to the Emergency Department of Imam-khomeini Hospital (Sari, Iran).

The study protocol was approved by the Local Ethics Committee of Mazandaran University of Medical Sciences and was performed in accordance with the ethical standards of the 1964 Declaration of Helsinki. All data are confidential and patient anonymity is preserved. 
Inclusion criteria were age between 15 and 60 years and multiple or major trauma (falling from more than three-metre height; thrown from a vehicle; one or more mortality among vehicle occupants; motorcyclist with speed over $32 \mathrm{~km} / \mathrm{h}$; four-wheeled-vehicle occupant in a crash with speed over $64 \mathrm{~km} / \mathrm{h}$, any fourwheeled vehicle deformation of more than $50 \mathrm{~cm}$, or more than $30 \mathrm{~cm}$ on the occupant's side; out-of-vehicle waiting time of more than $20 \mathrm{~min}$; rollover collision; and pedestrian-car collisions at speeds over $8 \mathrm{~km} / \mathrm{h}$ ).

Exclusion criteria were: decreased level of consciousness $(\mathrm{GCS}<15)$; patients suspicious for poisoning; and any underlying renal, haematological, or hepatic disease that could confound the test results.

Based on Fisher's formula $\left(N=[1.96]^{2} \times 4 p[1-p] / d^{2}\right)$, using data from previous studies [11], assuming a confidence level of $95 \%$ and confidence interval of $1 \%$, the minimum sample size was determined to be 340 cases

Data gathering was performed by the main researcher of the study, who referred to emergency department of Imam Khomeini Hospital (Sari, Iran) in different shifts, days, and months of the year 2018, and selected cases based on inclusion and exclusion criteria.

Demographic data including age, gender, mechanism of trauma, injured body region, and clinical findings were recorded in the patient's profile form. Frequency and results of routine ordered tests for each patient were added to their profile. Injury Severity Score (ISS) and Abbreviated Injury Scale (AIS) were calculated for each case, and the results were documented in the patients' profiles.

Routine tests were defined as $\mathrm{CBC} / \mathrm{UA} / \mathrm{BUN} / \mathrm{Cr}$ / $\mathrm{NA} / \mathrm{K} / \mathrm{PT} / \mathrm{PTT}$, which were all analysed in the Central Laboratory of Imam-khomeini Hospital.

The AIS is an anatomical-based coding system created by the Association for the Advancement of Automotive Medicine to classify and describe the severity of injuries. It is on a scale of one to six, one being a minor injury and six being maximal (currently untreatable).

The ISS is an established medical score to assess trauma severity. It correlates with mortality, morbidity, and hospitalisation time after trauma. To calculate an ISS, the highest AIS severity code in each of the three most severely injured body regions are calculated, each AIS code is squared, and then the three squared numbers are added together for an ISS (ISS = $\mathrm{A} 2+\mathrm{B} 2+\mathrm{C} 2$, where A, B, C are the AIS scores of the three most injured ISS body regions).

All cases were followed up to their final diagnosis, which was logged in their profile, as well as total time of admission in the Emergency Department and/or Hospitalisation.

\section{Statistical analysis}

Data were transferred to computer, and statistical analysis was performed using SPSS (v.21) software. To determine the effective factors on reaching the final diagnosis the $\chi^{2}$ and logistic regression tests were used. To evaluate the congruity of nominal variables the $\chi^{2}$ test was used. Logistic regression was performed to predict bi-variate dependent variables. $P$-value less than 0.05 was considered significant.

\section{Results}

A total of 340 cases completed this descriptivecross sectional study during the year 2017. Two hundred and forty-four cases were male $(71.8 \%)$. Mean age of patients was $32.77 \pm 12.47$ years, ranging from 15 to 65 years. The distribution of the number of individuals in each age group revealed that the most populous was age group 20-29 years (119 cases, 35.0\%) followed by $30-39$ years ( 82 cases, $24.1 \%$ ). Data are shown in Table 1.

Thew mechanism of trauma was evaluated. The three most common types of trauma were car occupant (41.8\%), motorcyclist (27.4\%), and pedestrian-car collision (24.7\%) (Table 2). The mechanism of trauma based on gender was also evaluated; however, Fisher's exact test did not reveal a statistically significant relationship between gender and mechanism of trauma ( $p=0.081)$.

Injured body regions were studied, the most common injured body regions were lower extremity (36.88\%), upper extremity (32.6\%), abdomen (16.8\%), and head and neck (15\%) (Table 3$)$.

Clinical findings from trauma patients were studied, and the most common were pain (92.4\%), tenderness (90.9\%), skin abrasion (87.9\%), and swelling (62.1\%). Data are shown in Table 4.

The frequency of ordered routine tests in trauma patients was studied, and the most common tests were CBC, PT, and PTT. Data are shown in Figure 1.

The relationship between clinical findings and results from lab tests in trauma patients was evaluated based on logistic regression test, in which lab results were considered as probable and clinical findings as independent variables. The only statistically significant relationship was between swelling (clinical finding) and biochemistry results $(p=0.034)$.

All participants were followed up to their final diagnosis, and the results were evaluated. Final diagnosis in $150(44.1 \%)$ cases was fractures, in 185 (54.4\%)

Table 1. Distribution of trauma patients in each age group

\begin{tabular}{|lcc|}
\hline $\begin{array}{l}\text { Age group } \\
\text { [years] }\end{array}$ & $\begin{array}{c}\text { Number } \\
\text { of individuals }\end{array}$ & Percentage \\
$15-19$ & 39 & 11.5 \\
$20-29$ & 119 & 35.0 \\
$30-39$ & 82 & 24.1 \\
$40-49$ & 62 & 18.2 \\
$50-59$ & 20 & 5.9 \\
$\geq 60$ & 18 & 5.3 \\
\hline
\end{tabular}


Table 2. Distribution of trauma patients based on mechanism of trauma and gender

\begin{tabular}{|lccc|}
\hline Mechanism of trauma & Total & Male gender & Female gender \\
4-wheeled vehicle occupant & $142(41.8 \%)$ & $112(78.9 \%)$ & $30(21.1 \%)$ \\
Motorcyclist & $93(27.4 \%)$ & $60(64.5 \%)$ & $33(35.5 \%)$ \\
Pedestrian/car collision & $84(24.7 \%)$ & $57(67.9 \%)$ & $27(32.1 \%)$ \\
Fall from height & $10(2.9 \%)$ & $8(80.0 \%)$ & $2(20.0 \%)$ \\
Direct hit & $6(1.8 \%)$ & $5(83.3 \%)$ & $1(16.7 \%)$ \\
Other & $5(1.5 \%)$ & $2(40 \%)$ & $3(60 \%)$ \\
Total & 340 & $244(71.8 \%)$ & $56(28.2 \%)$ \\
\hline
\end{tabular}

Table 3. Distribution of injured body regions in trauma patients

\begin{tabular}{|lcc|}
\hline Injured body region & Frequency & Percentage \\
Upper extremity & 111 & 32.6 \\
Lower extremity & 125 & 36.8 \\
Head and neck & 51 & 15.0 \\
Thorax & 36 & 10.6 \\
Spine & 18 & 5.3 \\
Pelvis & 28 & 8.2 \\
Abdomen & 57 & 16.8 \\
Other & 6 & 1.8 \\
\hline
\end{tabular}

Table 4. Distribution of clinical findings in trauma patients

\begin{tabular}{|lcc|}
\hline $\begin{array}{l}\text { Clinical examination } \\
\text { findings }\end{array}$ & Percentage & Frequency \\
Pain & 92.4 & 314 \\
Tenderness & 90.9 & 309 \\
Swelling & 62.1 & 211 \\
Ecchymosis & 35.9 & 122 \\
Abrasion & 87.9 & 299 \\
Laceration & 33.2 & 113 \\
Crepitation & 17.6 & 60 \\
\hline
\end{tabular}

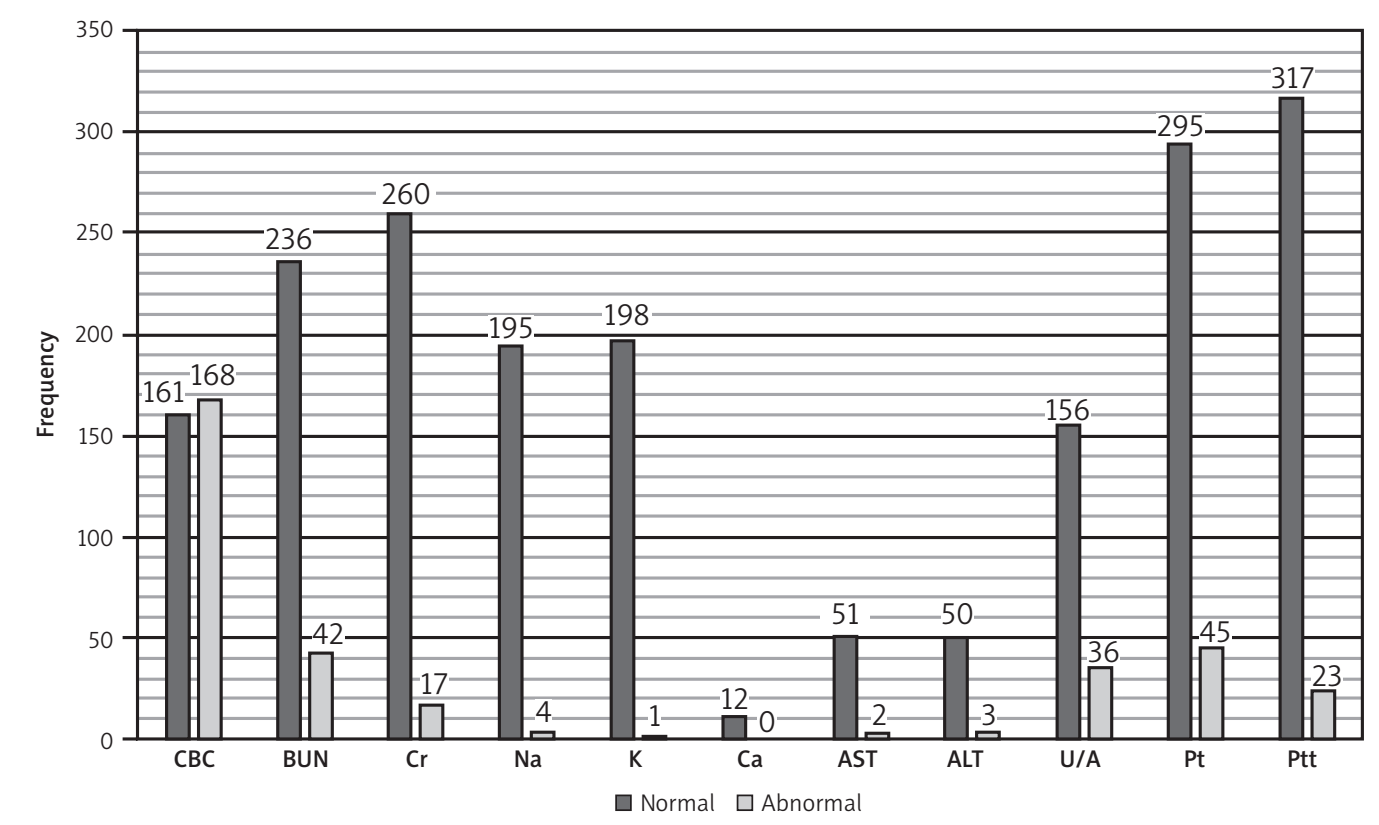

Figure 1. Frequency of ordered routine tests in trauma patients

cases it was multiple trauma, and in $5(1.5 \%)$ cases it was stab wound (Table 5).

Mean time of admission in the Emergency Department was $25.09 \pm 8.79 \mathrm{~h}$, ranging between 12 and
$48 \mathrm{~h}$. Mean time of hospitalisation was $3.00 \pm 2.05$ days, ranging between 0 and 9 days.

The relationship between final diagnosis and results from lab tests in trauma patients was evaluated 
bases on Fisher's exact test, in which no statistically significant relationship was found $(p \geq 0.05)$.

\section{Discussion}

Trauma is an important public health issue and the leading cause of death in the population of patients aged below 45 years [10]. However, about 90\% of patients referred to Emergency Departments do not have serious and life-threatening injuries. Therefore, the most appropriate laboratory and screening tests should be ordered in accordance with the primary problem of the patients. In the present study, the necessity of routine lab tests ordered in Emergency Departments for trauma patients are evaluated. Every unnecessary test imposes an additional medical and economic burden on patients and the health system. In a prospective study by Ozlem Koksal et al., aiming to evaluate the necessity and diagnostic value of routine lab tests in trauma patients presented to Emergency Departments, which included 103 cases, the mean age of patients was 97/12 35/35 years, and 30.1\% of patients were female. $72.8 \%$ of cases presented with motor-vehicle accidents, $12.6 \%$ with pedestrian-car collisions, and $14.6 \%$ had fallen from a height. They concluded that biochemistry tests, PA chest X-rays, and pelvis X-rays can be ordered targeted, which will reduce the costs and working load. However, the unicentral nature of the study and the small sample size were considered as limitations [10]. Although the sample size in our study was larger, both studies indicated that lab tests in Emergency Departments are not targeted.

In another study by Tasse et al., aiming to evaluate the costs of routine lab tests and radiological panels in trauma patients during a 3-month period, 410 cases with 3982 tests (at a cost cost of $\$ 417,839$ ) were studied. Among them, 1292 tests $(\$ 114,753)$ were abnormal, and in only 253 cases $(\$ 36,703)$ the results were clinically helpful. They concluded that a huge number of these tests and radiological imagings are merely an extra burden for patients and health systems and almost $\$ 1,500,000$ coul be saved annually by way of further studies and better-quality managements [11]. The difference between the mentioned study and ours is that in the present study the costs imposed on the health system were not evaluated, which is recommended for future studies.

In a pilot single-centre, prospective descriptive study, by Nagurney et al., which was designed in order to measure the utilisation and diagnostic value of tests used in the Emergency Department on patients with undifferentiated non-traumatic abdominal or flank pain, 124 subjects with a mean age of 44 years were enrolled. Based on serial provider interviews pre- and post-testing, they measured the frequency of change of the most likely diagnosis and disposition, which tests were performed, and the provider-
Table 5. Frequency of final diagnosis in trauma patients

\begin{tabular}{|lcc|}
\hline Final diagnosis & Frequency & Percentage \\
Fracture of upper extremity & 123 & 36.2 \\
Fracture of lower extremity & 141 & 41.5 \\
Head and neck injury & 15 & 4.4 \\
Death & 4 & 1.2 \\
Spinal injury & 5 & 1.5 \\
Haemothorax & 4 & 1.2 \\
Pelvis fracture & 5 & 1.5 \\
Intra-abdominal organ injury & 4 & 1.2 \\
Normal & 39 & 11.5 \\
\hline
\end{tabular}

perceived value of tests. Testing led to a change in the most likely diagnosis in $37 \%$ of subjects, and in disposition in $41 \%$. The frequency of diagnostic test use varied from a high of $93 \%$ for CBC to $6 \%$ for blood or urine culture. Overall, 65\% of patients had at least one imaging study performed, and 39\% had an abdominal/pelvic computed tomography (CT) scan. Among all subjects, the providers identified the most useful tests as the CT scan (31\%) and urinalysis (17\%). Researchers concluded that among trauma patients who presented with non-traumatic abdominal or flank pain, the pre-test most likely diagnosis and disposition were changed based on the ED evaluation in over one-third of subjects. Almost all received blood tests and two-thirds received one or more imaging studies. Based on the providers' subjective opinions, the most valuable tests were the abdomino/pelvic computed tomography (CT) scan and urinalysis [12]. Similar to the present study, the most frequently ordered lab test was complete blood count (CBC), and the difference lies in the lack of evaluation of imaging studies, which can be recommended for future studies.

Different research projects have studied other variables in trauma patients referred to Emergency Departments, among which Hosseini et al. can be named for their cross-sectional study, which aimed to calculate the chronometric indices of patients' workflow in Emergency Departments and to determine their associated factors. They evaluated 649 records of patients attending an ED, and demographic data, route of entrance (EMS/walk-in), traumatic/non-traumatic types, time durations, lab test and imaging requests, other service visits, and work-shift data were collected and analysed. Mean time between triage to visit was $22 \mathrm{~min}$, visit to disposition was $210 \mathrm{~min}$, disposition to exit was $51 \mathrm{~min}$, and triage to disposition was $243 \mathrm{~min}$. There was no statistically significant relationship between durations and sex, traumatic/nontraumatic patients, and shift of work. However, a statistically significant relationship did exist between durations and route of entrance, lab test and imaging 
requests, surgery and neurosurgery visits with triage to visit, visit to disposition, and disposition to exit. Researchers concluded that the mean triage to visit, visit to disposition, disposition to exit, and triage to disposition durations were closer to them, and these differences are related to the route of entrance, lab test and imaging requests, surgery, and neurosurgery visits [13].

In another study by Rasoolnajad et al., researchers evaluated the process of performing emergency tests in Shahid Madani Hospital in Tabriz. The findings from their study revealed that the intervals between sampling by a nurse in an Emergency Department and delivery of the sample to the lab, and also the interval between sample analysis and delivery of the results to the emergency department, are the main cause of delay. They also stated that the main cause of delay in sample analysis was the nonexistence of a laboratory in the department and the spent time performing unnecessary laboratory tests [14]. The researchers concluded that unnecessary laboratory tests delayed the service process and therefore there must be focus on performing tests with diagnostic value.

\section{Conclusions}

Findings from our study revealed that the most frequently ordered lab tests in patients who presented to our Emergency Department with major trauma are CBC, followed by PT and PTT. In addition, routine laboratory tests are not targeted; therefore, reducing unnecessary ordered lab tests may reduce health costs. Further extensive studies with larger populations regarding the use of diagnostic tests and costeffectiveness, not only in trauma patients, but also related to other medical issues, should be done to study the use of targeted tests. Imaging test evaluation is also recommended.

\section{Acknowledgments}

The authors would like to thank Dr Ramzani for his assistance.

\section{Conflict of interest}

The authors declare no conflict of interest.

\section{References}

1. Vali L. Evaluation of structures of emergency departments and NICU and its relationship with pediatric moratlity rates in specialized pediatric hospitals in Tehran [mastership thesis]. Tehran: Tehran University of Medical Sciences, 1381.

2. Rahimi B. Evaluation of structure, process and function of emergency departments in academic hospitals of Uromeia and Tabriz [mastership thesis]. Tehran: Tehran University of Medical Sciences 1378.
3. Rahmani H, Arab M, Akbari F, Zeraati H. Structure, process and performance of the emergency unit of teaching hospitals of Tehran University of Medical Sciences. sjsph 2006; 4: 13-22.

4. Vesico M, Donahoe P. An organizational wide approach to improving ED patient satisfaction one community feading hospital. J Emerg Nurs 1999; 25: 192-198.

5. Hustetler J, Teft S. Patient need in the emergency department. J Nurs Administration 1999; 43: 29-50.

6. Ergene U, Fowler J. Cost Effectiveness of Diagnostic Tests in Emergency Medicine. 1st ed. Süleyman Demirel University Publications 1999; 5-11.

7. Tasse J, Janzen M, Ahmed N, Chung R. Screening laboratory and radiology panels for trauma patients have low utility and are not cost effective. J Trauma 2008; 65: 11141116.

8. Ersoy G, Karcioğlu O, Enginbaş Y, User N. Should all patients with blunt trauma undergo 'routine' pelvic X-ray? Eur J Emerg Med 1995; 2: 65-68.

9. American College of Surgeons Committee on Trauma. Advanced trauma life support for doctors student course manual. 7th ed. American College of Surgeons, Chicago 2004.

10. Köksal Ö, Çevik ŞE, Aydin A, Özdemir F. Analysis of the necessity of routine tests in trauma patients in the emergency department. Ulus Travma Acil Cerrahi Derg 2012; 18: 23-30.

11. Tasse J, Janzen M, Ahmed N, Chung R. Screening laboratory and radiology panels for trauma patients have low utility and are not cost effective. J Trauma 2008; 65: 11141116.

12. Nagurney J, Brown D, Chang Y, Sane S, Wang A, Weiner J. Use of diagnostic testing in the emergency department for patients presenting with non-traumatic abdominal pain. J Emerg Med 2003; 25: 363-371.

13. Hosseini M, Shaker H, Ghafouri H, Shokraneh F. Chronometric study of patients' workflow and effective factors on it in emergency department of $7^{\text {th }}$ Tir Martyrs Hospital of Tehran, Iran. J Health Administ 2010; 13: 13-22.

14. Rasoolnajad N, Shami E, Gholipoor K, Bijanpoor H, Nasrollahi F, Sherkati S. Evaluating the process of performing emergency tests in Shahid Madani Hospital in Tabriz by FOCUS-PDCA method. 2012: 22-8.

\section{Address for correspondence:}

Seyed Mohammad Hosseininejad

Diabetes Research Centre

Faculty of Medicine

Mazandaran University of Medical Sciences

Sari, Iran

E-mail: amamali110@gmail.com 